\title{
ABSOLUTE PRODUCTION OF RADIOCARBON AND THE LONG-TERM TREND OF ATMOSPHERIC RADIOCARBON
}

\author{
Tomasz Goslar \\ Institute of Physics, Silesian University of Technology, ul. Krzywoustego 2, 44-100 Gliwice, Poland. \\ Email: goslar@zeus.polsl.gliwicwe.pl.
}

\begin{abstract}
This paper presents simulations of the long-term trend of atmospheric radiocarbon, performed with the modified PANDORA model. The author shows that taking into account the outflow-supply carbon fluxes makes the decrease of $\mathrm{D}^{14} \mathrm{C}$ between 40 and $0 \mathrm{ka}$ BP larger by $40-80 \%$, not much depending on which data (sedimentary magnetism, archaeomagnetism or ${ }^{10} \mathrm{Be}$ ) is used for the scenario of relative variations of ${ }^{14} \mathrm{C}$ production. This, together with the effect of $\mathrm{CO}_{2}$ increase reasonably reconciles model-simulated and observed decline of atmospheric $\Delta^{14} \mathrm{C}$.
\end{abstract}

\section{INTRODUCTION}

It was recognized long ago that the secular variations of atmospheric radiocarbon concentration were related to changes of ${ }^{14} \mathrm{C}$ production in the Holocene (e.g. Stuiver et al. 1991) as well as in the Glacial (e.g. Bard et al. 1990). This relationship is mostly due to the screening effect of Earth's magnetic field on cosmic rays, which produce ${ }^{14} \mathrm{C}$ in the atmosphere.

During the last decade, studies of secular ${ }^{14} \mathrm{C}$ variations have been extensively developed. One line of development is the progress of ${ }^{14} \mathrm{C}$ calibration (Stuiver et al. 1993, 1998; Kitagawa and van der Plicht 1998; Schramm et al. 2000) which documents continuous decline of atmospheric ${ }^{14} \mathrm{C}$ over the last 40,000 years (Figure 1). The second one is an issue of independent data on cosmogenic production. These data include paleomagnetic reconstructions, based on archeomagnetic (McElhinny and Senanayake 1982) and sedimentary magnetic (e.g. Tric et al. 1992; Guyodo et al. 1996) studies, and more direct reconstructions of cosmic rays, which use ${ }^{10} \mathrm{Be}$ concentrations in sediments (Frank et al. 1997). Using such data and the global carbon cycle models, Mazaud et al. (1992) and Bard (1997a, 1998) concluded that the decline of $\Delta{ }^{14} \mathrm{C}$ is well explained by secular changes of cosmic-ray intensity.

The rate of $\Delta^{14} \mathrm{C}$ decline, simulated in the studies above, was slower than that documented with the ${ }^{14} \mathrm{C}$ calibration data. That discrepancy was considered insignificant regarding uncertainty of proxy data. This uncertainty has been expressed (Figure 1a) with the bands representing range of "possible" $\Delta{ }^{14} \mathrm{C}$. The upper and lower limits of those bands have been obtained with model simulations, using the highest and lowest possible values of ${ }^{14} \mathrm{C}$ production, deduced from the uncertainty of the proxy data.

However, influence of rapid fluctuations of ${ }^{14} \mathrm{C}$ production on atmospheric ${ }^{14} \mathrm{C}$ concentration is attenuated by the carbon cycle, which acts as a low-pass filter. Therefore rapid changes of $\Delta^{14} \mathrm{C}$ within the bands in Figure 1a may require fluctuations of ${ }^{14} \mathrm{C}$ production larger that those allowed by the uncertainty of the production data. Such is the case of the ${ }^{14} \mathrm{C}$ record (Figure 1b). The deviation of the required ${ }^{14} \mathrm{C}$ production from that allowed by the proxy data is not large. However, between $20 \mathrm{ka}$ and today, all the proxies consequently predict higher ${ }^{14} \mathrm{C}$ production than the required one. This may reflect some additional factor responsible for the secular changes of atmospheric ${ }^{14} \mathrm{C}$ concentration.

\section{ABSOLUTE PRODUCTION RATE OF RADIOCARBON}

The reservoir models of the global carbon cycle (e.g. Oeschger et al. 1975; Broecker et al. 1990; Bard 1997b) deal with relative changes of ${ }^{14} \mathrm{C}$ production and concentration. Here, the production rate is expressed in relation to the modern production, and ${ }^{14} \mathrm{C}$ concentration is expressed with rela-

(C) 2001 by the Arizona Board of Regents on behalf of the University of Arizona

Radiocarbon, Vol 43, Nr 2B, 2001, p 743-749

Proceedings of the 17 th International ${ }^{14} \mathrm{C}$ Conference, edited by I Carmi and E Boaretto 
tion to the standard of modern biosphere. In the steady state, the models predict standard ${ }^{14} \mathrm{C}$ concentration in the atmosphere for the modern value of ${ }^{14} \mathrm{C}$ production.

However, the existing models do not properly explain the absolute value of ${ }^{14} \mathrm{C}$ production. This production should counterbalance radioactive decay of ${ }^{14} \mathrm{C}$, which can be calculated using ${ }^{14} \mathrm{C}$ inventories in model reservoirs. That question has been raised by Damon (1988), and Damon and Sternberg (1989) pointed out that the model-calculated rate of ${ }^{14} \mathrm{C}$ decay is about $30 \%$ smaller than that determined using direct measurements of neutron fluxes in the atmosphere.
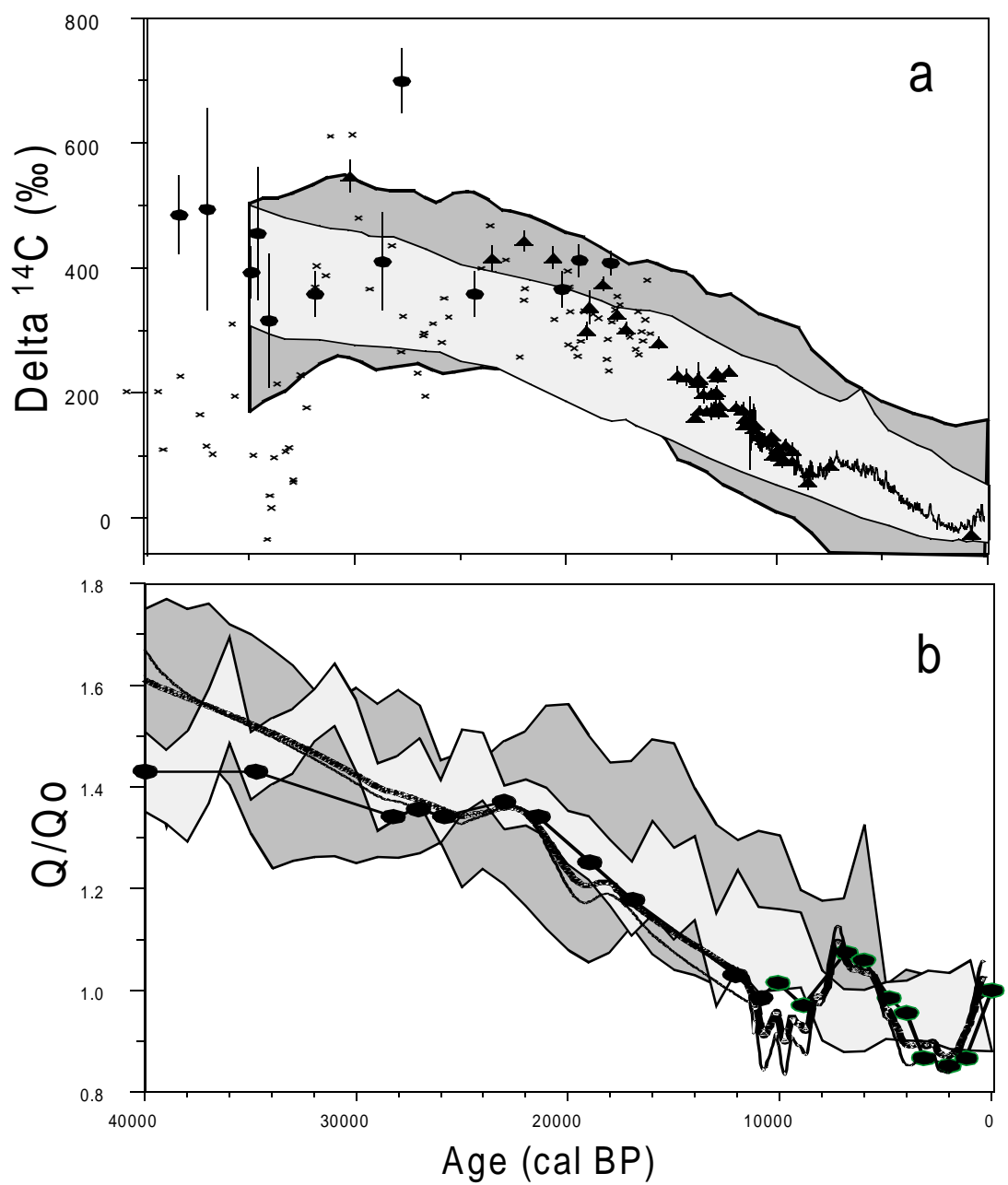

Figure 1a Atmospheric $\Delta^{14} \mathrm{C} v s$. time calculated using the ${ }^{14} \mathrm{C}$ calibration data from: $\boldsymbol{\Delta}=$ corals (Bard et al. 1998), $-=$ European oak and pines (Stuiver et al. 1998), $X=$ Lake Suigetsu, Japan (Kitagawa and van der Plicht 1998), and - Lake Lisan, Israel (Schramm et al. 2000). Light and dark bands represent range of $\Delta^{14} \mathrm{C}$ calculated by Bard (1997a, 1998) using the paleomagnetic (Guyodo et al. 1996) and the ${ }^{10} \mathrm{Be}$ (Frank et al. 1997) data, respectively. $b$ : Changes of radiocarbon production rate (in relation to the present production) $v s$. time. Thin and thick lines $=$ production rate required to explain the $\Delta^{14} \mathrm{C}$ changes documented by the tree-ring and coral data, calculated with the PANDORA model without and with the E-I fluxes, respectively. Dark and light bands $=$ ranges of ${ }^{14} \mathrm{C}$ production rate derived from the paleomagnetic (Guyodo et al. 1996) and the ${ }^{10} \mathrm{Be}$ (Frank et al. 1997) data, respectively. Line with solid circles $={ }^{14} \mathrm{C}$ production rate derived from the archaeomagnetic data (McElhinny and Senanayake 1992). 
Damon and Sternberg (1989) proposed that this apparent discrepancy is due to sedimentation of about 1.4 gigaton of carbon per year (GtC/yr), which transfers significant amounts of ${ }^{14} \mathrm{C}$ "out" of the usually considered carbon cycle. In their model, the main paths of carbon escape were deposition of carbonates at oceanic bottom (ca. $0.55 \mathrm{GtC} / \mathrm{yr}$ ), and deposition of organic matter (ca. $0.7 \mathrm{GtC} / \mathrm{yr}$ ) in coastal wetlands, deltas, lagoons, etc. with very long carbon residence time.

In the steady state, the escape must be balanced by inflow of ${ }^{14} \mathrm{C}$-free or ${ }^{14} \mathrm{C}$-depleted carbon. Damon and Sternberg (1989) assumed two fluxes of inactive carbon to the oceans, one (0.6 GtC/yr) from the atmosphere and the second one (ca. $0.8 \mathrm{GtC} / \mathrm{yr}$ ) directly from the continents. To keep constant the atmospheric inventory, the atmospheric outflow must be balanced by release from continents (from decomposition of "very old" organic matter, volcanic eruptions, etc.)

The escape-inflow (E-I) fluxes have been usually neglected in model simulations of past ${ }^{14} \mathrm{C}$ levels. This seems well justified, as in the steady state, ${ }^{14} \mathrm{C}$ concentrations in all reservoirs are proportional to the production rate, independently of which model type (i.e. with and without the E-I) is used. So, as the ${ }^{14} \mathrm{C}$ concentrations and ${ }^{14} \mathrm{C}$ production rate are expressed in relative units (i.e. with respect to the concentration in the preindustrial atmosphere, and with respect to the modern production rate, respectively) the results of simulations with the two model types would be identical.

However, one must realize that by incorporating the E-I fluxes, we allow for $30 \%$ higher absolute changes of the production rate, while the amount of carbon in the atmosphere-ocean-biosphere system remains the same. Therefore, the response of ${ }^{14} \mathrm{C}$ concentration to given relative change of the production rate is stronger in the models with than without the E-I flux. The difference is strongest in the case of very quick changes, but may be significant even for changes with a time constant comparable to the half-life of ${ }^{14} \mathrm{C}$.

\section{MODELING THE E-I FLUXES}

One of models used for calculations of past ${ }^{14} \mathrm{C}$ variations (Goslar et al. 1995, 1999, 2000) is the PANDORA model (Broecker et al. 1988). In these calculations, the sedimentation was being neglected. Nevertheless, if we assume that the specific ${ }^{14} \mathrm{C}$ activity in the preindustrial atmosphere $\left(\Delta^{14} \mathrm{C}=0 \%\right.$ o $)$ was $14.1 \mathrm{dpm} / \mathrm{gC}$, the PANDORA model gives preindustrial steady-state ${ }^{14} \mathrm{C}$ decay rate of $1.66 \mathrm{dps} / \mathrm{cm}^{2}$. This value is distinctly lower than the absolute production rate, which for the period 1964-1976 averaged at 2.2-2.35 at/ $\mathrm{cm}^{2}$ s (compiled from Light et al. 1973; Korff and Mendel 1980; Castagnoli and Lal 1980; Lal 1988, 1992).

The ${ }^{14} \mathrm{C}$ production and decay may be balanced when we allow for an escape of $1.85 \mathrm{GtC} / \mathrm{yr}$ "out" of the system. In fact, that value is independent of the form (i.e. whether organic or carbonate) of escaping carbon. It is worth to note, that bibliographic data on carbon fluxes to sediments are quite diverse (e.g. $F_{\text {org }}=0.4-1.3 \mathrm{GtC} / \mathrm{yr}$ - Baes et al. $1985 ; \mathrm{F}_{\text {org }}=1 \mathrm{GtC} / \mathrm{yr}-\mathrm{Olson}$ et al. $1985 ; \mathrm{F}_{\text {carb }}=0.4 \mathrm{GtC} / \mathrm{yr}$ and $\mathrm{F}_{\text {org }}=0.35 \mathrm{GtC}-$ Mackenzie et al. $1993 ; \mathrm{F}_{\text {org }}=2.2 \mathrm{GtC} / \mathrm{yr}-$ Wollast $1993 ; \mathrm{F}_{\text {org }+ \text { carb }}=0.2 \mathrm{GtC} / \mathrm{yr}-$ Siegenthaler and Sarmiento 1993).

In the standard PANDORA model, about $1.3 \mathrm{GtC} / \mathrm{yr}$ precipitates in the surface oceans in form of carbonates. Using the mean depth of the lysocline (4500 m; Broecker and Takahashi 1978), one can estimate that about $35 \%$ of that flux is ultimately deposited to sediments. So, the resulting sedimentary flux of carbonates (ca. $0.45 \mathrm{GtC} / \mathrm{yr}$ ) is quite similar to that proposed by Damon and Sternberg (1989). Nevertheless, in previous ${ }^{14} \mathrm{C}$ simulations, the whole precipitating carbonate was assumed to dissolve in deeper reservoirs. In the E-I modification, the escape (total $1.85 \mathrm{GtC} / \mathrm{yr}$ ) is provided by fluxes of carbon out of the surface ocean reservoirs (Figure 2). 


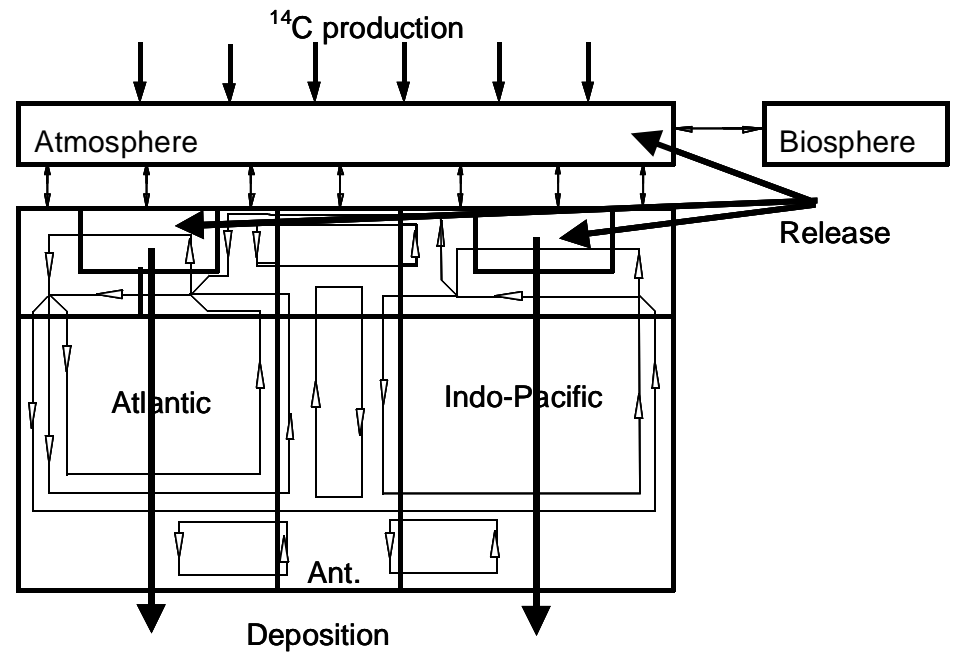

Figure 2 Schematic representation of the fluxes in the PANDORA model (Broecker et al. 1990). The fluxes introduced to balance the decay and production of radiocarbon are displayed with thick arrows.

The pathway of inflow of inactive carbon (which balances the escape) is meaningful for ${ }^{14} \mathrm{C}$ distribution between reservoirs, as the ${ }^{14} \mathrm{C}$-free carbon dissolves ${ }^{14} \mathrm{C}$ in the recipient reservoir. This problem has not been analyzed before. In the model, I assumed that half of inactive carbon is supplied to the atmosphere, and the second half to the surface ocean (Figure 2). This would increase reservoir age of surface ocean by around 130-140 years, an effect which must be compensated by increased $\mathrm{CO}_{2}$ exchange between oceans and atmosphere (from $15 \mathrm{~mol} / \mathrm{m}^{2} \mathrm{yr}$ to $19.5 \mathrm{~mol} / \mathrm{m}^{2} \mathrm{yr}$ ). Such an increase, however, seems difficult to accept, since even the value of $15 \mathrm{~mol} / \mathrm{m}^{2} \mathrm{yr}$ is $15 \%$ higher than that calculated theoretically using known wind distribution over the oceans (Etcheto et al. 1991). Therefore, this problem requires further study.

\section{MODELING THE LONG-TERM TREND OF ATMOSPHERIC ${ }^{14} \mathrm{C}$}

Recent simulations of long-term changes of atmospheric ${ }^{14} \mathrm{C}$ have been published by Bard (1997a, 1998), who used several scenarios of cosmogenic production. Two scenarios were based on the reconstructions of geomagnetic dipole moment, with the relationship between relative changes of geomagnetic field and production taken from Lal (1998). The third scenario used the measurements of ${ }^{10} \mathrm{Be}$ concentration in sediments. The changes of beryllium are proportional to the changes of cosmogenic production.

I used the same scenarios. To determine the effect of absolute ${ }^{14} \mathrm{C}$ production, each scenario was run on two versions of the PANDORA model i.e. without and with the E-I fluxes. The results obtained with the standard model (Figure 3) are very similar to those of Bard (1997a, 1998). All the scenarios predict decline of atmospheric $\mathrm{D}^{14} \mathrm{C}$ distinctly slower than that documented by the ${ }^{14} \mathrm{C}$ calibration data. Taking into account the E-I fluxes makes the decline during the last 30 ka larger by $40-80 \%$, and closer to the real one. The increase of the rate of decline, caused by the E-I mechanism, is similar for all the scenarios of ${ }^{14} \mathrm{C}$ production. 


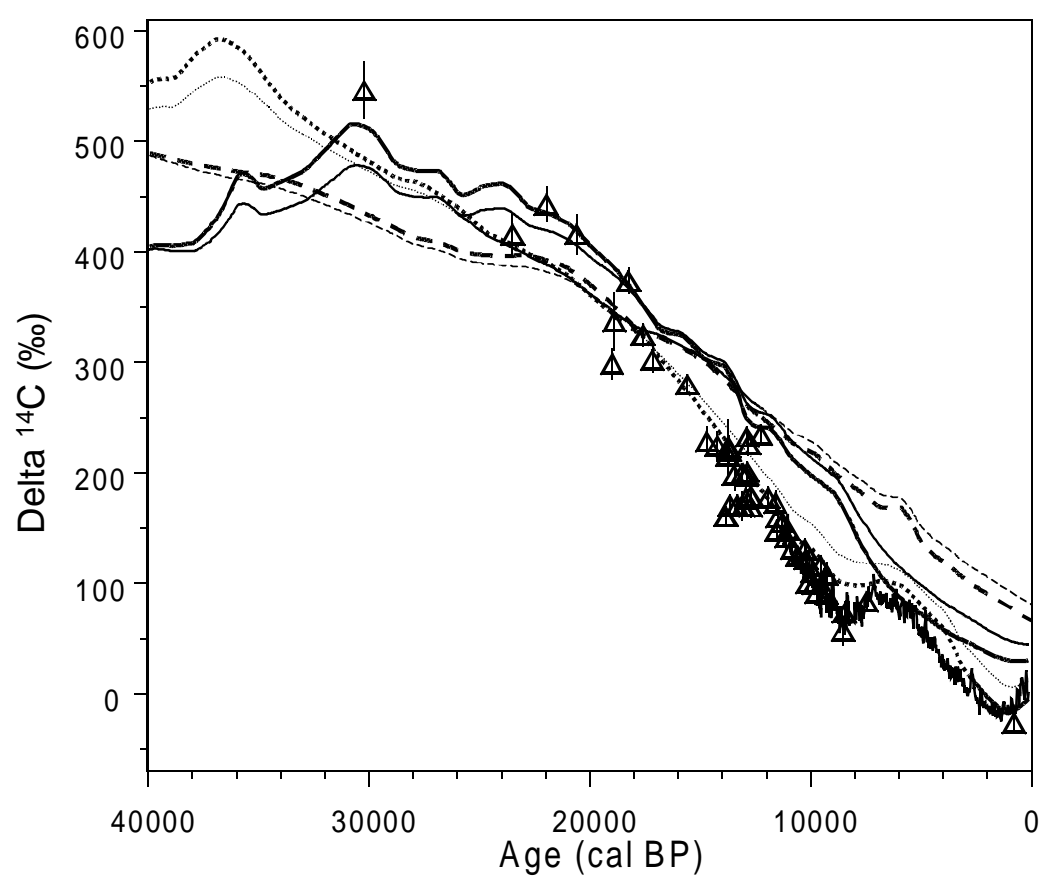

Figure 3 Results of simulations of atmospheric $\Delta{ }^{14} \mathrm{C}$ using the PANDORA model without (thin lines) and with (thick lines) the E-I fluxes. The line types differentiate input data on the cosmonuclide production. Dashed lines $=$ sedimentary paleomagnetic data (Guyodo et al. 1996), solid lines $={ }^{10} \mathrm{Be}$ data $($ Frank et al. 1997), dotted lines $=$ archaeomagnetic data (McElhinny and Senanayake 1992). The values of $\Delta^{14} \mathrm{C}$ calculated from $\Delta=$ corals (Bard et al. 1998) and - = European oak and pines (Stuiver et al. 1998) are shown for comparison.

\section{CONCLUSION}

Deposition of ${ }^{14} \mathrm{C}$-bearing carbon in oceanic sediments, balanced by the release of ${ }^{14} \mathrm{C}$-free carbon from the continents is a mechanism, which may reconcile the model-derived and measured absolute rates of modern ${ }^{14} \mathrm{C}$ production. Taking this (E-I) mechanism into account affects the results of model simulations of past ${ }^{14} \mathrm{C}$ concentration, making the decline of $\Delta{ }^{14} \mathrm{C}$ during the last $30 \mathrm{ka}$ larger by $60 \%$. This diminishes discrepancy between observed long-term decline of atmospheric $\Delta^{14} \mathrm{C}$ and that, which can be explained by the long-term changes of ${ }^{14} \mathrm{C}$ production rate.

Another factor is the increase of $\mathrm{CO}_{2}$ concentration between the Glacial and the Holocene. This change would decrease atmospheric $\Delta^{14} \mathrm{C}$ by around 25-35\% (Lal and Revelle 1984; Keir 1983; Goslar et al. 1999), further increasing the rate of decline of $\Delta^{14} \mathrm{C}$, towards the observed trend.

One serious problem of the E-I approach is that both the E and I fluxes could vary in time. Such variations are partly constrained by the known history of atmospheric $\mathrm{CO}_{2}$ concentration, nevertheless, simultaneous changes of both $\mathrm{E}$ and I fluxes, which would affect atmospheric ${ }^{14} \mathrm{C}$ with no changing $\mathrm{CO}_{2}$ concentration, are beyond control. This problem, however, is beyond the scope of this paper. 


\section{ACKNOWLEDGMENTS}

This study has been sponsored by Silesian University of Technology, through the project BW/ RMF1/2000.

\section{REFERENCES}

Baes CF Jr, Börkström A, Mulholland PJ. 1985. Uptake of carbon dioxide by the oceans. In: Trabalka JR, editor. Atmospheric carbon dioxide and the global carbon cycle. US Department of Energy Report DOE/ ER-0239. p 83-111.

Bard E, Hamelin B, Fairbanks RG, Zindler A. 1990. Calibration of ${ }^{14} \mathrm{C}$ timescale over the past 30,000 years using mass spectrometric U-Th ages from Barbados corals. Nature 345:405-10.

Bard E. 1997a. Nuclide production by cosmic rays during the last ice age. Science 277:532-3.

Bard E, Raisbeck GM, Yiou F, Jouzel J. 1997b. Solar modulation of cosmogenic nuclide production over the last millennium: comparison between ${ }^{14} \mathrm{C}$ and ${ }^{10} \mathrm{Be}$ records. Earth and Planetary Science Letters 150: 453-62.

Bard E. 1998a. Geochemical and geophysical implications of the radiocarbon calibration. Geochimica et Cosmochimica Acta 62:2025-38.

Bard E, Arnold M, Hamelin B, Tisnerat-Laborde N, Cabioch G. 1998b. Radiocarbon calibration by means of mass spectrometric ${ }^{230} \mathrm{Th} /{ }^{234} \mathrm{U}$ and ${ }^{14} \mathrm{C}$ ages of corals: an updated database including samples from Barbados, Mururoa and Tahiti. Radiocarbon 40(3):1085-92.

Broecker WS, Peng TH, Trumbore S, Bonani G, Wölfli W. 1990. The distribution of radiocarbon in the Glacial Ocean. Global Biogeochemical Cycles 4:103-17.

Broecker WS, Takahashi T. 1978. The relationship between lysocline depth and in situ carbonate ion concentration. Deep Sea Research 25:65-95.

Castagnoli G, Lal D. 1980. Solar modulation effects in terrestrial production of carbon-14. Radiocarbon 22(3): 133-58.

Damon PE. 1988. Production and decay of radiocarbon and its modulation by geomagnetic field-solar activity changes with possible implications for global environment. In: Stephenson FR, Wolfendale W, editors. Secular solar and geomagnetic variations in the last 10,000 years. Kluwer Academic Publishers. p 315-28.

Damon PE, Sternberg RE. 1989. Global production and decay of radiocarbon. Radiocarbon 31:697-703.

Etcheto J, Boutin J, Merlivat L. 1991. Seasonal variations of the $\mathrm{CO}_{2}$ exchange coefficient over the global ocean using satellite wind speed measurements. Tellus 43B: 247-55.

Frank M, Schwarz B, Baumann S, Kubik PW, Suter M, Mangini A. 1997. A 200 kyr record of cosmogenic radionuclide production rate and geomagnetic field intensity from ${ }^{10} \mathrm{Be}$ in globally stacked deep-sea sediment. Earth and Planetary Science Letters 149:121-9.
Goslar T, Arnold M, Bard E, Kuc T, Pazdur MF, RalskaJasiewiczowa M, Tisnerat N, Różański K, Walanus A, Wicik B, Więckowski, K. 1995. High concentration of atmospheric ${ }^{14} \mathrm{C}$ during the Younger Dryas cold episode. Nature 377:414-7.

Goslar T, Wohlfarth B, Björck S, Possnert G, Björck J. 1999. Variations of atmospheric ${ }^{14} \mathrm{C}$ concentrations over the Alleröd-Younger Dryas transition. Climate Dynamics 15:29-42.

Goslar T, Arnold M, Tisnerat-Laborde N, Czernik J, Więckowski K. 2000. Variations of Younger Dryas atmospheric radiocarbon explicable without ocean circulation changes. Nature 403:877-80.

Guyodo Y, Valet JP. 1996. Relative variations in geomagnetic intensity from sedimentary records in the past 200,000 years. Earth and Planetary Science Letters 143:23-36.

Keir RS. 1983. Reduction of thermohaline circulation during deglaciation: the effect on atmospheric radiocarbon and $\mathrm{CO}_{2}$. Earth and Planetary Science Letters 64: 445-56.

Kitagawa H, van der Plicht J. 1998. Atmospheric radiocarbon calibration to 45,000 yr B.P.: late glacial fluctuations and cosmogenic isotope production. Science 279:1187-90.

Korff SA, Mendell RB. 1980. Variations in radiocarbon production in the Earth's atmosphere. Radiocarbon 22:159-65.

Lal D. 1988. Theoreticaly expected variations in the terrestrial cosmic-ray production of isotopes. In SolarTerrestrial relationships and the Earth environment in the last millenia. Societa Italiana di Fisica, Bologna, Italy, 95:216-33.

Lal D. 1992. Expected secular variations in the global terrestrial production rate of radiocarbon. In: Bard E, Broecker WS, editors. The Last Deglaciation: absolute and radiocarbon chronologies. Springer-Verlag. $\mathrm{p}$ 113-26.

Lal D, Revelle R. 1984. Atmospheric $\mathrm{pCO}_{2}$ changes recorded in lake sediments. Nature 308:344-6.

Light ES, Merker M, Verschell HJ, Mendell RB, Korff SA. 1973. Time-dependent world wide distribution of atmospheric neutrons and of their products, II, Calculation. Journal of Geophysical Research 78:2741-62.

Mackenzie FT, Ver LM, Sabine C, Lane M, Lerman A. 1993. C, N, P, S global biogeochemical cycles and modeling of global change. In: Wollast R, Mackenzie FT, Chou L, editors. Interactions of $C, N, P$ and $S$ biogeochemical cycles and global change. Springer-Verlag. p 1-62. 
Mazaud A, Laj C, Bard E, Arnold M, Tric E. 1991. Geomagnetic field control of ${ }^{14} \mathrm{C}$ production over the last $80 \mathrm{ky}$ : implications for the radiocarbon time-scale. Geophysical Research Letters 18:1885-8.

McElhinny MW, Senanayake WE. 1982. Variations in the Geomagnetic Dipole 1: the past 50,000 years. Journal of Geomagnetism and Geoelectricity 34:3951.

Oeschger H, Siegenthaler U, Schotterer U, Gugelmann A. 1975. A box-diffusion model to study the carbon dioxide exchange in nature. Tellus 27:169-92.

Olson JS, Garrels RM, Berner RA, Armentano TV, Dyer MI, Yaalon DH. 1985. The natural carbon cycle. In: Trabalka JR, editor. Atmospheric carbon dioxide and the global carbon cycle. US Department of Energy Report DOE/ER-0239. p 177-213.

Schramm A, Stein M, Goldstein SL. 2000. Calibration of the ${ }^{14} \mathrm{C}$ time scale to $40 \mathrm{ka}$ by ${ }^{234} \mathrm{U}^{230} \mathrm{Th}$ dating of Lake Lisan sediments (last glacial Dead Sea). Earth and Planetary Science Letters 175:27-40.

Siegenthaler U, Sarmiento JL. 1993. Atmospheric carbon dioxide and the ocean. Nature 365:119-25.
Stuiver M, Braziunas T, Becker B, Kromer B. 1991. Climatic, solar, oceanic, and geomagnetic influences on Late-Glacial and Holocene atmospheric ${ }^{14} \mathrm{C} /{ }^{12} \mathrm{C}$ change. Quaternary Research 35:1-24.

Stuiver M, Long A, Kra RS, editors. 1993. Calibration 1993. Radiocarbon 35(1): $244 \mathrm{p}$.

Stuiver M, van der Plicht J, editors. 1998. INTCAL98. Radiocarbon 40(3): 123 p.

Stuiver M, Reimer PJ, Bard E, Warren Beck J, Burr GS, Hughen KA, Kromer B, McCormac G, van der Plicht J, Spurk M. 1998. INTCAL98 radiocarbon age calibration, 24,000-0 cal BP. Radiocarbon 40(3): 104183.

Tric E, Valet JP, Tucholka P, Paterne M, Labeyrie L, Guichard F, Tauxe, L, Fontugne M. 1992. Paleointensity of the Geomagnetic field during the last 80,000 years. Journal of Geophysical Research B97:9337-51.

Wollast R. 1993. Interactions of carbon and nitrogen cycles in the coastal zone. In: Wollast R, Mackenzie FT, Chou L, editors. Interactions of $C, N, P$ and $S$ Biogeochemical Cycles and Global Change. SpringerVerlag. p 195-210. 